\title{
Experimental infection of white spot baculovirus in some cultured and wild decapods in Taiwan
}

\author{
Yu-Chi Wang ${ }^{\mathrm{b}}$, Chu-Fang Lo a, Poh-Shing Chang ${ }^{\mathrm{b}}$, \\ Guang-Hsiung Kou ${ }^{\text {a, * }}$ \\ ${ }^{a}$ Department of Zoology, National Taiwan University, Taipei, Taiwan \\ ${ }^{\mathrm{b}}$ Department of Aquaculture, National Kaohsiung Institute of Marine Technology, Kaohsiung, Taiwan
}

\begin{abstract}
Techniques for the detection of white spot baculovirus virus (WSBV) by polymerase chain reaction are well established. In this study, two primer sets designed from an isolate of WSBV from Penaeus monodon, PmNOB III, were used to detect WSBV infection in cultured and wild decapods in Taiwan. WSBV positive cases were found in all of four major marine cultured shrimp, P. monodon, P. japonicus, P. penicillatus and Metapenaeus ensis. Wild P. semisulcatus was also found to be naturally infected by WSBV. On the other hand, no cases of naturally occurring WSBV infection have yet been found in the wild shrimp Exopalaemen orientalis (from a milkfish culture farm), Trachypenaeus curvirostris, M. ensis (from the coast of Taiwan), Macrobrachium sp. and Procambarus clarkii (from rivers in Taiwan). Furthermore, neither the wild crabs, Calappa lophos, Portunus sanguinolentus, Charybdis granulata and C. feriata, nor the wild lobsters Panulirus ornatus, $P$. versicolor, P. longipes and P. penicillatus, collected from the coast of Taiwan showed any evidence of being naturally infected by WSBV. When captured specimens of these decapods were artificially infected by feeding them with tissues from severely PmNOB III infected P. monodon, wild shrimp mortality reached moderate to high levels at 18 days post infection. Using PCR analysis, WSBV DNA could be detected in the moribund specimens during the experimental period and in the survivors on the final day of the experiment. The mortalities in wild crabs and lobsters, however, were not significantly different from control groups. Nevertheless, WSBV DNA was also detectable in these specimens. WSBV was thus shown to have a wide host range and to exhibit different infectivity in the various decapods investigated in the present study. (C) 1998 Elsevier Science B.V. All rights reserved.
\end{abstract}

Keywords: White spot syndrome; White spot baculovirus (WSBV); Polymerase chain reaction; Host range

\footnotetext{
${ }^{*}$ Corresponding author. Department of Zoology, National Taiwan University, Taipei, Taiwan. Fax: 886-2-363-8179
} 


\section{Introduction}

White spot baculovirus (WSBV) is the causative agent of a severe shrimp viral disease which is characterized by white spots on the exoskeleton and epidermis of affected shrimp (Lightner, 1996). Since 1992, this disease has caused high mortalities and serious damage to the shrimp culture industry of Taiwan and other Asian countries (Inouye et al., 1994; Momoyama et al., 1994; Nakano et al., 1994; Takahashi et al., 1994; Chou et al., 1995; Wang et al., 1995). It has also occurred in cultured shrimp in the southern United States and resulted in mass mortality in 1995 (personal communication with Harlingen Shrimp Farm). Electron microscopic examination has revealed the causative viral agent to be a rod-shaped, enveloped, nonoccluded baculovirus (Chou et al., 1995; Inouye et al., 1994; Momoyama et al., 1994; Nakano et al., 1994; Takahashi et al., 1994; Wang et al., 1995). Histopathological study demonstrates that WSBV targets various tissues originating from both the mesoderm and ectoderm, as evidenced by the presence of degenerated cells with hypertrophied nuclei in the tissues examined (Chou et al., 1995; Momoyama et al., 1994; Wang et al., 1995; Chang et al., 1996). Based on the morphology of the WSBV, its histopathological characteristics and DNA content, WSBV is closely related to Japan's rod-shaped nuclear virus of P. japonicus (RV-PJ) (Inouye et al., 1994), China's hypodermal and hematopoietic necrosis baculovirus (HHNBV) (Cai et al., 1995) and Thailand's systematic ectodermal and mesodermal baculovirus (SEMBV) of the black tiger prawn P. monodon (Wongteerasupaya et al., 1995).

WSBV is extremely virulent and has a wide host range. The currently known hosts of WSBV include the penaeid shrimp $P$. japonicus, $P$. monodon, $P$. chinensis and $P$. penicillatus (Cai et al., 1995, Wang et al., 1995). The infectivity of WSBV in other marine shrimp (such as $M$. ensis, which is another important cultured shrimp in Taiwan), freshwater shrimp and lobsters, crabs and other decapods is still unknown. In this study, recently established polymerase chain reaction techniques (Lo et al., 1996) were used to detect natural WSBV infection in various cultured and captured decapods in Taiwan. In order to investigate the infectivity of WSBV, specimens which were not naturally infected by WSBV were fed with severely WSBV diseased P. monodon and subsequently tested for infection by PCR assay.

\section{Materials and methods}

\subsection{Sample sources}

Four major species of cultured shrimp, P. monodon, P. japonicus, P. penicillatus and $M$. ensis were collected from different culture farms at Kaohsiung in Taiwan from May to September 1995. Penaeus monodon, P. japonicus and P. penicillatus were collected from culture farms which recently had an outbreak of white spot syndrome. Samples from these three species were used as a positive control for the PCR technique. Specimens of $M$. ensis, which has not yet been reported as a host of WSBV, were also collected from a culture farm which had suffered massive losses. These shrimp also 
displayed white spot syndrome and all were examined for WSBV natural infection by PCR analysis. The following decapods without any evidence of white spot syndrome were collected during the course of the study: wild marine shrimps P. semisulcatus, $T$. curvirostris and M. ensis from the southwestern coast of Taiwan from October 1995 to January 1996, wild Exopalaemon orientalis from a milkfish (Chanos chanos) culture farm, wild freshwater shrimps, Macrobrachium sp. and Proc. clarkii from the rivers in southwestern Taiwan in December 1995, wild marine crabs Cal. lophos, Port. sanguinolentus, Charybdis granulata, and C. feriata from the seaport at Kaohsiung in Taiwan between November 1995 to February 1996, four kinds of lobster, Pan. ornatus, P. versicolor, $P$. longipes, and $P$. penicillatus, from the coast of Pintung in the south of Taiwan in January 1996. All these wild specimens were sent to the laboratory immediately after being caught and checked for natural WSBV infection by PCR analysis.

\subsection{Deproteinized DNA extraction}

Either the pereiopods, pleopods or gills of the collected samples were chosen for deproteinized DNA extraction because the cuticular epidermis of these tissues is one of the first targets of WSBV infection (Chang et al., 1996). The protocols for the extraction of deproteinized DNA from the tissues of shrimp, crabs and lobsters followed those described in Lo et al. (1996).

\subsection{Primers and PCR amplification}

The oligonucleotide primers 146F1 and 146R1, which were designed on the basis of the DNA sequence of a cloned PmNOB III 1461 bp SalI DNA fragment in recombinant plasmid (pms146), were used to amplify the WSSV DNA fragments. Then the internal primers $146 \mathrm{~F} 2$ and $146 \mathrm{R} 2$ were used to increase sensitivity about $10^{3}$ to $10^{4}$ times relative to the first PCR amplification (unpublished data). The primers 143F and 145R with highly conserved regions of the $18 \mathrm{~S}$ rRNA sequence of decapods were used to qualitatively assess the extracted DNA. Details on the primers and PCR amplification protocols can be found in Lo et al. (1996).

\subsection{Experimental infection in wild decapods}

Before the infectivity trials began, the seawater decapods were acclimated in 501 plastic tanks containing filtered, aerated sea water (salinity $25 \mathrm{ppt}$ ) at ambient temperature (approximately $22-27^{\circ} \mathrm{C}$ ) for at least one day. In case of the freshwater shrimp, filtered and aerated fresh water was used. For M. ensis and E. orientalis, 10 to 15 shrimps were kept in a 501 tank. For wild T. curvirostris, Macrobrachium sp. and Proc. clarkii, 20 to 30 shrimps were kept in one 501 tank. In the case of crabs and lobsters, two or three specimens were kept in 501 plastic tanks. The experimental decapods that found to be free of WSBV infection using two step PCR amplification detection were tested for WSBV infectivity by artificially infecting with WSBV from $P$. monodon (PmNOB III). The infection groups were fed severe PmNOB III-infected $P$. monodon for one meal and then with artificial diet for the subsequent days. Control 
groups were fed artificial diet. The mortality was recorded daily and the moribund or recently dead specimens were used to prepare DNA templates for PCR analysis.

\section{Results}

\subsection{Natural WSBV infection in cultured shrimp}

Results of the amplification of WSBV DNA from deproteinized DNA prepared from the pereiopods and pleopods of the four major cultured shrimp in Taiwan are shown in Fig. 1a and $\mathrm{b}$. The presence of the $1,447 \mathrm{bp}$ product after the first PCR amplification in P. monodon, P. japonicus, P. penicillatus and $M$. ensis confirmed a large amount of WSBV in these samples and also indicated the natural infection of WSBV in M. ensis. After reamplification with internal primers, these test samples also yielded the $941 \mathrm{bp}$ PCR product. Some specimens which did not give positive results in the first PCR step
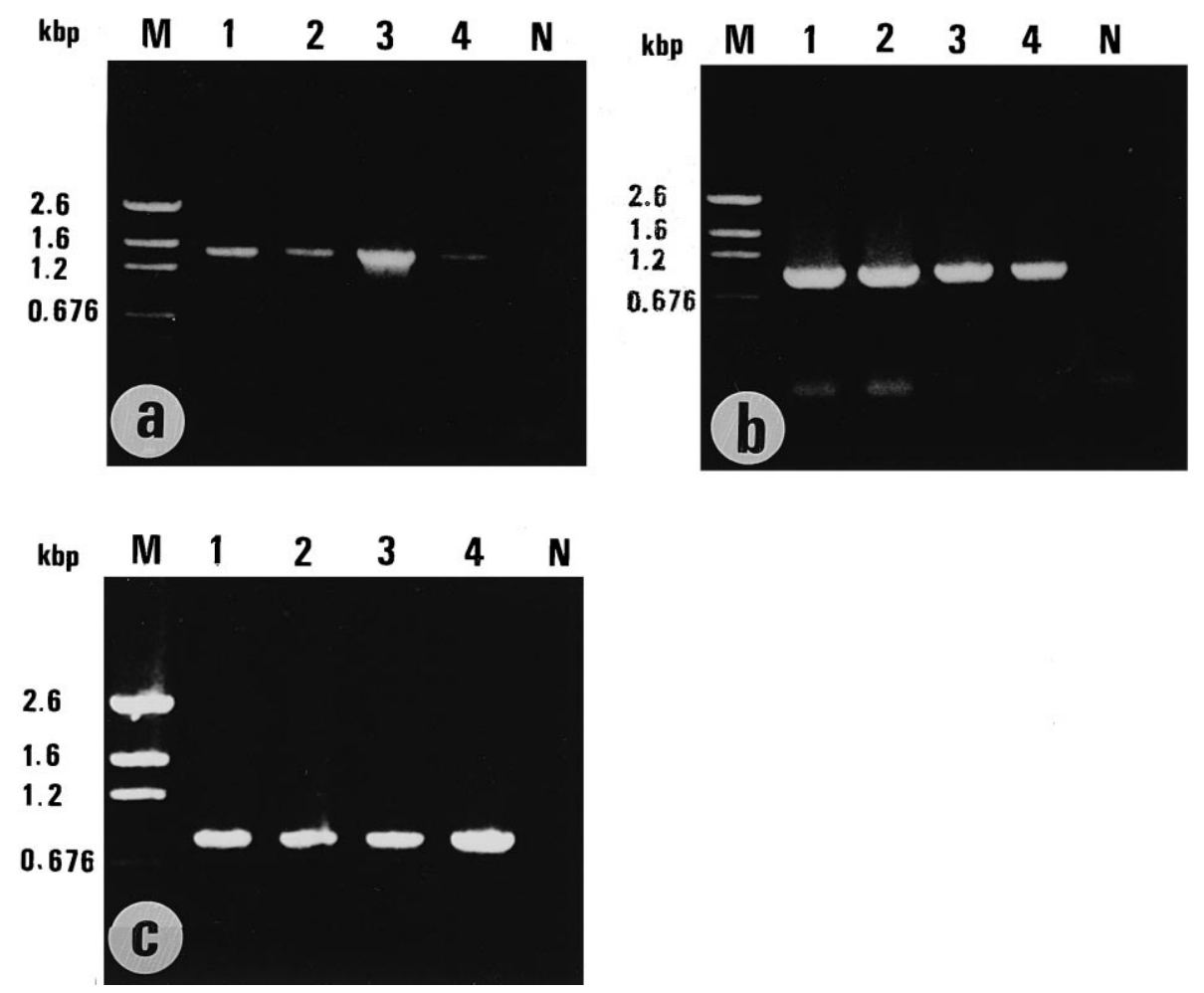

Fig. 1. PCR detection of WSBV DNA in cultured shrimp. (a): first PCR amplification using primers 146F1 and 146R1 for WSBV DNA. (b): second PCR amplification using primers 146F2 and 146R2 for WSBV DNA. (c): shrimp DNA amplification using primers $143 \mathrm{~F}$ and $145 \mathrm{R}$ for 18 s RNA. M: pGEM DNA marker. N: template free control. Lane 1: Penaeus monodon, Lane 2: P. japonicus, Lane 3: P. penicillatus, Lane 4: Metapenaeus ensis. 
Table 1

Detection of natural WSBV infection in cultured shrimp in Taiwan by external symptoms and PCR analysis

\begin{tabular}{lcrrl}
\hline Species & Size $(\mathrm{g})$ & WSS $^{\mathrm{a}}$ & PCR I $^{\mathrm{b}}$ & PCR II $^{\mathrm{c}}$ \\
\hline Penaeus monodon & $8-10$ & $7 / 12$ & $9 / 12$ & $12 / 12$ \\
P. japonicus & $10-12$ & $9 / 14$ & $11 / 14$ & $14 / 14$ \\
$P$. penicillatus & $4-6$ & $10 / 12$ & $10 / 12$ & $12 / 12$ \\
Metapenaeus ensis & $6-8$ & $7 / 10$ & $8 / 10$ & $10 / 10$ \\
\hline
\end{tabular}

${ }^{\text {a }}$ No. of shrimp with white spot syndrome/total no. of samples.

${ }^{\mathrm{b}}$ No. of shrimp giving the $1447 \mathrm{bp}$ PCR product/total no. of samples.

${ }^{\mathrm{c}}$ No. of shrimps giving the $941 \mathrm{bp}$ PCR product/total no. of samples.

nonetheless gave a positive result after reamplification (Table 1). The fact that the DNA prepared from each test sample yielded an almost equal amount of the $848 \mathrm{bp} \mathrm{PCR}$ product, which is the amplification product of shrimp 18S rRNA sequence, argues against the occurrence of false negative results due to low quantities of the DNA template (Fig. 1c).

\subsection{Natural WSBV infection in wild decapods}

The results of WSBV PCR analysis for wild-caught decapods are shown in Table 2. WSBV was only detected in the wild $P$. semisulcatus and then only after the second PCR amplification (Fig. 2). All the other examined specimens yielded the decapod 18S rRNA 848 bp product after amplification (data not shown), but did not show any positive result in either the first or the second PCR detection.

Table 2

Detection of natural WSBV infection in wild shrimp, crabs and lobsters in Taiwan by external symptoms and PCR analysis

\begin{tabular}{lclll}
\hline Species & Size $(\mathrm{g})$ & WSS $^{\mathrm{a}}$ & $\mathrm{PCR} \mathrm{I}^{\mathrm{b}}$ & PCR II $^{\mathrm{c}}$ \\
\hline Exopalaemon orientalis & $0.5-1.2$ & $0 / 11$ & $0 / 11$ & $0 / 11$ \\
Penaeus semisulcatus & $8-10$ & $0 / 15$ & $0 / 15$ & $4 / 15$ \\
Trachypenaeus curvirostris & $3-5$ & $0 / 20$ & $0 / 20$ & $0 / 20$ \\
Metapenaeus ensis & $8-12$ & $0 / 12$ & $0 / 12$ & $0 / 12$ \\
Macrobrachium sp. & $0.4-1.2$ & $0 / 25$ & $0 / 25$ & $0 / 25$ \\
Procambarus clarkii & $4-7$ & $0 / 24$ & $0 / 24$ & $0 / 24$ \\
Calappa lophos & $100-120$ & $0 / 10$ & $0 / 10$ & $0 / 10$ \\
Portunus sanguinolentus & $105-117$ & $0 / 12$ & $0 / 12$ & $0 / 12$ \\
Charybdis granulata & $95-115$ & $0 / 8$ & $0 / 8$ & $0 / 8$ \\
Charybdis feriata & $112-121$ & $0 / 10$ & $0 / 10$ & $0 / 10$ \\
Panulirus ornatus & $26-32$ & $0 / 5$ & $0 / 5$ & $0 / 5$ \\
Panulirus versicolor & $45-52$ & $0 / 5$ & $0 / 5$ & $0 / 5$ \\
Panulirus longipes & $115-125$ & $0 / 5$ & $0 / 5$ & $0 / 5$ \\
Panulirus penicillatus & $158-172$ & $0 / 5$ & $0 / 5$ & $0 / 5$ \\
\hline
\end{tabular}

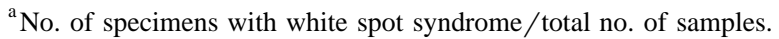

${ }^{\mathrm{b}}$ No. of specimens giving the $1447 \mathrm{bp}$ PCR product/total no. of samples.

${ }^{c}$ No. of specimens giving the $941 b p$ PCR product/total no. of samples. 


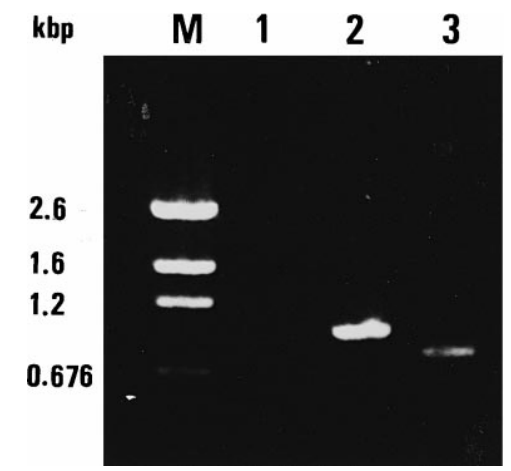

Fig. 2. PCR detection of WSBV DNA in captured P. semisulcatus. M: pGEM DNA marker. Lane 1: first PCR amplification using primers $146 \mathrm{~F} 1$ and $146 \mathrm{R} 1$ for WSBV DNA, Lane 2: second PCR amplification using primers $146 \mathrm{~F} 2$ and $146 \mathrm{R} 2$ for WSBV DNA, Lane 3: shrimp DNA amplification using primers $143 \mathrm{~F}$ and $145 \mathrm{R}$ for 18 s RNA.

\subsection{WSBV experimental infection in wild shrimp}

By the PCR results described above, the wild marine shrimps, E. orientalis, M. ensis, and T. curvirostris, and the wild freshwater shrimps, Macrobrachium sp. and Proc. clarkii were verified to be initially free of any natural WSBV infection. The cumulative mortality rates of these species after being fed WSBV-infected P. monodon are shown in Table 3. The mortality in experimental groups was higher than the respective control groups 18 days post infection. However, the mortalities were different among those species.

The DNA prepared from pereiopods and pleopods of recently dead or moribund specimens of E. orientalis and $M$. ensis gave positive results in the first PCR diagnosis (Table 4). For T. curvirostris and Proc. clarkii, only one of fifteen and two of eighteen respectively were negative in the first PCR diagnosis. However, all the examined specimens in these four groups were two step diagnostic PCR positive. Thus, there were plenty of WSBV DNA in these recently dead or moribund shrimps to implicate WSBV

Table 3

The cumulative mortality $(\%)$ of captured shrimp after experimental infection

\begin{tabular}{|c|c|c|c|c|c|c|c|c|c|c|}
\hline \multirow[t]{2}{*}{ Species } & \multirow[t]{2}{*}{$N$} & \multirow[t]{2}{*}{ Size $(g)$} & \multirow[t]{2}{*}{ WSS } & \multicolumn{7}{|c|}{ Cumulative mortalities (\%) } \\
\hline & & & & $3 d$ & $6 \mathrm{~d}$ & $9 \mathrm{~d}$ & $12 d$ & $15 d$ & $18 \mathrm{~d}$ & $\mathrm{C} *$ \\
\hline Exopalaemon orientalis & 28 & $0.5-0.8$ & 3 & 7 & 25 & 54 & 71 & 82 & 89 & 11 \\
\hline Trachypenaeus curvirostris & 36 & $3-5$ & 4 & 8 & 14 & 31 & 42 & 61 & 72 & 11 \\
\hline Metapenaeus ensis & 22 & $8-10$ & 3 & 17 & 27 & 55 & 68 & 91 & 91 & 9 \\
\hline Macrobrachium sp. & 55 & $0.4-1.2$ & - & 7 & 15 & 22 & 27 & 36 & 42 & 27 \\
\hline Procambarus clarkii & 32 & $4-7$ & 15 & 0 & 9 & 34 & 50 & 72 & 81 & 6 \\
\hline
\end{tabular}

$\mathrm{N}$ : Total no. of specimens in experimental and control groups. WSS: The day white spot syndrome appeared after infection. $\mathrm{C} *$ : Cumulative mortality in the respective control groups at the 18 th day post infection. 
Table 4

PCR detection of WSBV inwild-caught shrimp after feeding with WSBV infected P. monodon

\begin{tabular}{lcclll}
\hline Species & \multicolumn{2}{l}{ Dead or moribund $^{\mathrm{a}}$} & & \multicolumn{2}{l}{ Surviving $^{\mathrm{b}}$} \\
\cline { 2 - 3 } \cline { 6 - 6 } & PCR I & PCR II & & PCR I & PCR II \\
\hline Exopalaemon orientalis & $10 / 10$ & $10 / 10$ & & $1 / 3$ & $3 / 3$ \\
Trachypenaeus curvirostris & $14 / 15$ & $15 / 15$ & & $3 / 6$ & $6 / 6$ \\
Metapenaeus ensis & $10 / 10$ & $10 / 10$ & & $2 / 2$ & $2 / 2$ \\
Macrobrachium sp. & $5 / 15$ & $9 / 15$ & & $1 / 6$ & $3 / 6$ \\
Procambarus clarkii & $16 / 18$ & $18 / 18$ & & $2 / 6$ & $6 / 6$ \\
\hline
\end{tabular}

${ }^{\mathrm{a}}$ The template DNA for PCR was prepared from recently dead or moribund shrimp during the experimental period.

${ }^{\mathrm{b}}$ The template DNA for PCR was prepared from surviving shrimp $18 \mathrm{~d}$ after feeding.

PCR I: number of shrimp giving the $1447 \mathrm{bp}$ PCR product/total no. of samples.

PCR II: number of shrimp giving the $941 \mathrm{bp} \mathrm{PCR} \mathrm{product/total} \mathrm{no.} \mathrm{of} \mathrm{samples.}$

infection as the cause of death. On the other hand, only slightly over half of the dead or moribund wild Macrobrachium sp. gave positive results even after two step PCR diagnosis. Furthermore, while the cumulative mortality of the Macrobrachium sp. experimental group $18 \mathrm{~d}$ pi reached only $42 \%$, the mortality rate of the WSSV diagnostic PCR negative control group was $27 \%$. This suggests that Macrobrachium sp. is relatively non-susceptible to WSBV infection, but sensitive to some other factor. In this case, circumstantial evidence suggested that stress due to poor water quality is responsible.

Almost all of the surviving shrimp were also WSBV positive but the amount of WSBV DNA in these specimens was low because a higher proportion of the specimens gave positive results only after the second PCR (Table 4). This implies that the degree of WSBV infection in surviving individuals was lower than the dead or moribund individuals. Specimens from control groups, including those that died during the

Table 5

The cumulative mortality of wild crabs and lobsters after feeding WSBV infected P. monodon recorded as the number of dead specimens/total number of experimental specimens

\begin{tabular}{lllll}
\hline Species & \multicolumn{4}{l}{ Cumulative mortality } \\
\cline { 2 - 5 } & $5 \mathrm{~d}$ & $10 \mathrm{~d}$ & $20 \mathrm{~d}$ & $\mathrm{C} *$ \\
\hline Calappa lophos & $0 / 10$ & $1 / 10$ & $2 / 10$ & $1 / 10$ \\
Portunus sanguinolentus & $0 / 12$ & $3 / 12$ & $3 / 12$ & $2 / 12$ \\
Charybdis granulata & $0 / 8$ & $2 / 8$ & $2 / 8$ & $2 / 8$ \\
Charybdis feriata & $1 / 10$ & $1 / 10$ & $3 / 10$ & $2 / 10$ \\
Panulirus ornatus & $0 / 5$ & $0 / 5$ & $0 / 5$ & $0 / 5$ \\
Panulirus versicolor & $0 / 5$ & $0 / 5$ & $0 / 5$ & $0 / 5$ \\
Panulirus longipes & $0 / 5$ & $0 / 5$ & $0 / 5$ & $0 / 5$ \\
Panulirus penicillatus & $0 / 5$ & $0 / 5$ & $0 / 5$ & $0 / 5$ \\
\hline
\end{tabular}

$\mathrm{C} *$ : The cumulative mortality in the control group at the 20th day post infection. 
Table 6

PCR detection of WSBV in wild crabs and lobsters fed with WSBV infected P. monodon

\begin{tabular}{llllll}
\hline \multirow{2}{*}{ Species } & \multicolumn{2}{l}{ Dead or moribund } & & & \multicolumn{2}{l}{ Surviving $^{\mathrm{b}}$} & \\
\cline { 2 - 3 } \cline { 5 - 6 } & PCR I & PCR II & & PCR I & PCR II \\
\hline Calappa lophos & $0 / 2$ & $2 / 2$ & & $1 / 5$ & $4 / 5$ \\
Portunus sanguinolentus & $2 / 3$ & $3 / 3$ & & $2 / 5$ & $3 / 5$ \\
Charybdis granulata & $1 / 2$ & $2 / 2$ & $2 / 5$ & $4 / 5$ \\
Charybdis feriata & $1 / 3$ & $2 / 3$ & & $2 / 5$ & $3 / 5$ \\
Panulirus ornatus & - & - & $2 / 5$ & $3 / 5$ \\
Panulirus versicolor & - & - & $2 / 5$ & $4 / 5$ \\
Panulirus longipes & - & - & $2 / 5$ & $2 / 5$ \\
Panulirus penicillatus & - & - & $2 / 5$ & $4 / 5$ \\
\hline
\end{tabular}

${ }^{\mathrm{a}}$ The template DNA for PCR was prepared from recently dead or moribund crabs during the experimental period.

${ }^{\mathrm{b}}$ The template DNA for PCR was prepared from surviving crabs or lobsters $20 \mathrm{~d}$ after feeding.

PCRI: number of specimens giving the $1447 \mathrm{kbp}$ PCR product/total no. samples.

PCRII: number of specimens giving the 941 bp PCR product/total no. of samples.

experiment as well as the survivors, were second PCR negative. This reconfirms that no natural WSBV infection had occurred in wild shrimps.

\subsection{WSBV experimental infection in wild crabs and lobsters}

The wild crabs Cal. lophos, Port. sanguinolentus, C. granulata, and C. feriata, and the wild lobsters, Pan. ornatus, P. versicolor, P. longipes, and P. penicillatus, were initially WSBV-free as described above. At 20 days post feeding, mortalities in the experimental wild crab groups were not significantly different from control groups (Table 5). All the lobsters survived.

The gills and pereiopods of moribund or recently dead crabs of five of the surviving crabs and lobsters were used to prepare DNA for PCR analysis. All the dead crabs gave a second PCR positive result except one $C$. feriata. Two Port. sanguinolentus, one $C$. granulata and one $C$. feriata were first-step PCR positive (Table 6). WSBV could also be detected in surviving specimens. Three or four specimens out of five surviving crabs from each group gave positive results in two-step WSBV diagnostic PCR. These results suggest that WSBV was present in both the surviving and moribund crabs and that the degree of WSBV infection in surviving lobsters was similar to that of wild crabs. However, the lobsters seemed only lightly infected. Despite WSBV infection, these crabs and lobsters can evidently remain alive. Control groups were second PCR negative.

\section{Discussion}

The results of the present study indicate that in addition to $P$. monodon, $P$. japonicus and $P$. penicillatus, natural infection by WSBV can be found in cultured $M$. ensis and wild P. semisulcatus. None of the other wild decapods collected in this study was found 
to be naturally infected by WSBV. However, after experimental infection, WSBV was detected in these decapods by the PCR technique. This obviously suggests that these species can be naturally infected by WSBV upon contact. The known host range of WSBV is now extended from penaeid shrimp to other decapods, both fresh water and seawater species. Although not all decapods in Taiwan were studied, we can conclude that the host range of WSBV is very wide and the degree of WSBV infection is different among species.

From the results of experimental infection, WSBV infection can be classified into two types. Type 1 is an acute infection that causes high mortality within two weeks, such with $P$. penicillatus, M. ensis, E. orientalis, T. curvirostris, and Proc. clarkii in this study and in experimental groups of P. monodon, P. japonicus described by Chou et al. (1995) and Nakano et al. (1994). Type II infection is latent and most of the infected individuals are alive. Such was the case for WSBV infection in Macrobrachium sp., wild crabs (Cal. lophos, Port. sanguinolentus, C. granulata and C. feriata) and wild lobsters (Pan. ornatus, P. versicolor, P. longipes and P. penicillatus) in this study. Because WSBV did not cause disease symptoms, it is possible the wild crabs and lobsters are potential WSBV carriers. This may be the reason why there were no mass mortalities caused by epidemic white spot syndrome in culture crabs or lobsters in Taiwan or in other countries of Asia where white spot syndrome is serious.

Even within each infection type, different species exhibited various degrees of WSBV infection. Unfortunately, availability of wild shrimp, crabs and lobsters is limited and differences in sizes could not be controlled. This may be significant because others have reported that viruses have different infectivity in a single host species depending on size (Bell and Lightner, 1987; Chou et al., 1995). Thus, susceptibility to WSBV may be species- and size-specific. We also can not exclude the possibility that the experimental animals did not receive the same amount of virus because feeding method was used to introduce the disease. (Feeding is the natural way for a virus to spread in culture farms and the infection dosage becomes proportional to the weight of the animal.) Also, target organs of WSBV may have been different (Chang et al., 1998).

During the experimental period, white spot syndrome could be observed in wild $E$. orientalis, M. ensis, T. curvirostris, and Proc. clarkii but not in wild Macrobrachium sp. or any of the wild crabs or lobsters. Although it is easy to recognize, the time white spots appeared was different for each species. One factor that might this is the thickness of the exoskeleton. For example, Proc. clarkii has a thicker exoskeleton than the other shrimps and white spots appeared later. On the other hand, the results of in situ hybridization in experimentally infected P. monodon (Chang et al., 1996) suggest that the cuticular epidermis was initially infected by WSBV at $16 \mathrm{~h}$ pi and that the degree of infection became serious after $40 \mathrm{~h}$ pi. White spot syndrome was also observed $40 \mathrm{~h}$ pi. This implies that the appearance of white spot syndrome is related to the degree of infection in the cuticular epidermis under the carapace. Thus, the absence of white spots in infected wild freshwater Macrobrachium sp., crabs and lobsters may have been due to the low degree of WSBV infection in the cuticular epithelium. Future studies using in situ hybridization may help test this hypothesis.

This study indicates that the most common marine and fresh water decapods in Taiwan can be infected by WSBV, if not already potential carriers. This increases the 
probability of WSBV spreading from coastal regions to culture farms in the interior especially because shrimp farmers always add raw feeds (chopped fish, shrimp, crabs and clams) in addition to artificial diets (Liao, 1985). We, therefore, recommend that raw feeds not be used. To limit the spread of this disease, we also recommend that cleaning and decontamination of ponds be very carefully carried out to remove potential carriers.

\section{Acknowledgements}

This work was supported by the National Science Council under grant NSC 85-2321B-022-001 and the Council of Agriculture under grant No. 85-AST-1.1-FAD-49(21)A.

\section{References}

Bell, T.A., Lightner, D.V., 1987. IHHN disease of Penaeus stylirostris: effects of shrimp size on disease expression. J. Fish Dis. 10, 165-170.

Cai, S., Huang, J., Wang, C., Song, X., Sun, X., Yu, J., Zhang, Y., Yang, C., 1995. Epidemiological studies on the explosive epidemic disease of prawn in 1993-1994. J. Fish China 19, 112-117, (In Chinese).

Chang, P.S., Lo, C.F., Wang, Y.C., Kou, G.H., 1996. Identification of white spot syndrome associated baculovirus (WSBV) target organs in shrimp, Penaeus monodon, by in situ hybridization. Dis. Aquat. Org. 27, 131-139.

Chang, P.S., Chen, H.C., Wand, Y.C., 1998. Detection of white spot syndrome associated baculovirus (WSBV) in experimentally infected wild shrimps, crabs and lobsters by in situ hybridization. Aquaculture (In press).

Chou, H.Y., Huang, C.Y., Wang, C.H., Chiang, H.C., Lo, C.F., 1995. Pathogenicity of a baculovirus infection causing white spot syndrome in cultured penaeid shrimp in Taiwan. Dis. Aquat. Org. 23, 165-173.

Inouye, K., Miwa, S., Oseko, N., Nakano, H., Kimura, T., 1994. Mass mortalities of cultured kuruma shrimp, Penaeus japonicus, in Japan in 1993: electron microscopic evidence of the causative virus. Fish Pathol. 29, 149-158, (in Japanese).

Liao, I.C., 1985. A brief review of the larval rearing techniques of penaeid prawns. In: Taki, Y., Primavera, J.H., Llobrera, J.A. (Eds.), Proceedings of the First International Conference on the Culture of Penaeid Prawns/Shrimps. Aquaculture Department, Southeast Asian Fisheries Development Center, Iloilo, Philippines, pp. 65-78.

Lightner, D.V., 1996. A handbook of pathology and diagnostic procedures for diseases of penaeid shrimp. World Aquaculture Society, Baton Rouge, LA, USA, 305 pp.

Lo, C.F., Leu, J.H., Ho, C.H., Chen, C.H., Peng, S.E., Chen, Y.T., Chou, C.M., Yeh, P.Y., Huang, C.J., Chou, H.Y., Wang, C.H., Kou, G.H., 1996. Detection of baculovirus associated with white spot syndrome (WSBV) in penaeid shrimps using polymerase chain reaction. Dis. Aquat. Org. 25, 133-141.

Momoyama, K., Hiraoka, M., Nakano, H., Koube, H., Inouye, K., Oseka, N., 1994. Mass mortalities of cultured kuruma shrimp, Penaeus japonicus, in Japan in 1993: histopathological study. Fish Pathol. 29, 141-148, (in Japanese).

Nakano, H., Koube, H., Umezaea, S., Momoyama, K., Hiraoka, M., Inouye, K., Oseko, N., 1994. Mass mortalities of cultured kuruma shrimp, Penaeus japonicus, in Japan in 1993: epizootiological survey and infection trials. Fish Pathol. 29, 135-139, (in Japanese).

Takahashi, Y., Itami, T., Kondom, M., Maeda, M., Fujii, R., Tomonaga, S., Supamattaya, K., Boonyaratpalin, S., 1994. Electron microscopic evidence of bacilliform virus infection in Kuruma shrimp (Penaeus japonicus). Fish Pathol. 29, 21-125. 
Wang, C.H., Lo, C.F., Leu, J.H., Chou, C.M., Yeh, P.Y., Chou, H.Y., Tung, M.C., Chang, C.F., Su, M.S., Kou, G.H., 1995. Purification and genomic analysis of baculovirus associated with white spot syndrome (WSBV) of Penaeus monodon. Dis. Aquat. Org. 23, 239-242.

Wongteerasupaya, C., Vickers, J.E., Sriurairatana, S., Nash, G.L., Akarajamorn, A., Boonsaeng, V., Panyim, S., Tassanakajon, A., Withyachumnarnkul, B., Flegel, T.W., 1995. A non-occluded, systemic baculovirus that occurs in cells of ectodermal and mesodermal origin and causes high mortality in the black tiger prawn Penaeus monodon. Dis. Aquat. Org. 21, 69-77. 